\title{
Pain due to lesions of central nervous system removed by sympathetic block
}

\author{
L LOH, P W NATHAN, G D SCHOTT
}

\begin{abstract}
Eight patients were studied in whom a lesion within the central nervous system caused constant pain and hyperpathia. Blockade of the sympathetic supply to the periphery was carried out in each patient by stellate ganglion block or intravenous infusion of guanethidine $15 \mathrm{mg}$ in $30 \mathrm{ml}$ saline into a limb on the affected side. On almost every occasion the pain and hypersensitivity were reduced, sometimes completely.
\end{abstract}

Thus chronic pain and hyperpathia arising from a lesion in the central nervous system may be abolished by blocking the sympathetic supply to the periphery; this effect may be achieved when not all the peripheral nerves of the affected region have had their sympathetic nerve supply blocked. Such blockade may be worth repeating in the hope of achieving lasting relief of the intractable pain.

\section{Introduction}

Loh and Nathan ${ }^{1}$ reported the results of sympathetic blockade on certain peripheral nerve lesions with chronic pain and showed that such blockade was most likely to relieve the pain when it was associated with hyperpathia. They also concluded that an abnormal state of the peripheral nerves induced an abnormal state in related neurons of the spinal cord. In the present paper we describe lesions of the central nervous system associated with hyperpathia; in these cases too blocking the sympathetic supply of the affected region temporarily relieved the pain and hyperpathia. The sympathetic blocks were carried out either by infiltration of local anaesthetic into the sympathetic chain or by regional intravenous infusion of guanethidine into a limb. ${ }^{2}$

\section{Case reports}

We studied eight patients: table I shows the clinical features of each case and table II the effects of the sympathetic blocks. Cases 1, 4, and 8 are reported in detail below.

\section{CASE 1}

In 1978 this patient, a 31-year-old woman, received a severe closed head injury in a road traffic accident. On admission to hospital she was unconscious with a dilated right pupil, increased tone in the right arm and leg, and a Babinski response on the right. Within 24 hours she responded to commands and one week later was talking. Her condition continued to improve and she left hospital seven weeks later. At that time she had a tremulous voice, left facial paresis, mild right hemiplegia, and decreased tactile sensibility in the right leg. She started to have pain in the right leg about seven months after the accident, as the

\footnotetext{
The National Hospitals for Nervous Diseases, Queen Square, London WC1N 3BG

L LOH, MB, FFARCS, consultant anaesthetist

$P$ W NATHAN, MD, FRCP, honorary consultant

G D SCHOTT, MD, MRCP, consultant neurologis
}

decreased sensibility improved. By 14 months after the injury she was leading a fairly active life but was hindered by constant pain. This was of two kinds: a gripping, vice-like pain, mainly around the right ankle yet spreading to the knee and when maximal to the hip, and pain in the skin of the leg associated with considerable hypersensitivity that made even wearing clothes extremely uncomfortable. This pain was exacerbated by cold. When she flexed her toes she would get burning pain in the leg and toes. All her pains were made worse by walking and impeded movements of the leg.

On examination she had a tremulous voice, slight ataxia on turning, and unsustained nystagmus on looking to the left. There was myoclonus of the palate, the left vocal cord, and the musculature of the left lower face. The left gag reflex was absent. There was a slight intention tremor in the arms, more noticeable on the left. Tone was decreased in the left arm and increased in the right arm and leg; there was ankle clonus on the right. In the right leg all sensory stimuli felt abnormal; cold stimuli felt colder than in the rest of the body. There was extreme sensitivity to all forms of cutaneous stimulation of the entire right leg; it was maximal below the knee and spread proximally to just above the groin. When anything touched the leg she got an indescribable and unpleasant pain. Rubbing the skin was extremely painful. Pressing, squeezing, or pulling the muscles of the leg and even moving the foot or toes gave her a deep, burning pain.

We concluded that the brain stem had been badly damaged: the palatal myoclonus must have been due to a lesion of the right central tegmental tract or olive, or both, or the left cerebellum. The lesion causing the pain was probably due to the spinothalamic fibres being affected as they entered the left thalamus.

A regional infusion of $15 \mathrm{mg}$ guanethidine in $30 \mathrm{ml}$ isotonic saline was given into the right leg. During the 20 minutes for which the cuff was applied her spontaneous pains and the hypersensitivity of the skin and deep tissues subsided. She herself noticed that the sensitivity had been removed from the skin proximal to the cuff and was most surprised at this. Four days later she reported that the effect was lasting, though some slight sensitivity had returned. Another infusion of guanethidine, $20 \mathrm{mg}$ in $40 \mathrm{ml}$ saline, was given at this time. On removal of the cuff all pain and sensitivity had gone once again. Ten minutes after removing the cuff she could make extensive and rapid movements of the right ankle and toes; the pain on moving was absent. By eight hours after the infusion some of the tight pain had returned to the ankle vasodilatation was still complete. Twenty-four hours after the infusion the limb was still warmer than the other one and some more pain had returned to the ankle but the sensitivity on touching was still absent. The deep pain was improved but not removed; the sensitivity in the entire limb remained greatly improved so that stimuli felt almost normal.

CASE 4

The patient, a 66-year-old woman, awoke one morning in September 1977 to find that her right arm and leg were weak and she had numbness and diminished sensibility throughout the right side. During the next few months these improved, but as the hemianaesthesia became less she developed unpleasant sensations. The limbs had a strange sensation of being abnormally full, and there was burning pain. In March 1980 she described the pain as "boiling hot"; it was not in the skin but inside, "deep as though in the bones." There was another pain, as though the right arm and leg were being twisted, and she had a continuous sensation of pins and needles in the right side. She always wore a glove on the right hand, as when she touched anything or anything touched her hand or fingers she would get showers of pain "like electric shocks or red-hot needles." All the pain was relieved when the right arm and leg were supported, so that when she lay down she was free from pain. The pain was made worse by walking, not only because putting the right foot to the ground was painful but because walking made the abnormal sensations worse throughout the whole of her right side.

On examination a slight increase in tone and increased deep 
reflexes in the right arm and leg were found. These limbs tended to show unusual involuntary movements, which were best described as fidgety. On the right side of the body light touch and sharpness of pinprick were diminished but rubbing, gentle squeezing, or light touching, particularly when unexpected, made her withdraw the limb and caused pain like electric shocks or red-hot needles. Computed tomography showed evidence merely of moderate cerebral atrophy. The thalamic syndrome occurring after a cerebrovascular accident was diagnosed.

A right stellate ganglion block with $9 \mathrm{ml}$ of $0.5 \%$ bupivacaine was carried out. Within 10 minutes she said that "the awful pins and needles and burning and twisting pains" had gone. We were surprised to find that this was so not only for the right arm and face but also for the right leg. She started to use the right arm: she took off the glove and could pick up glasses and cups and use a knife and scissors. The arm could be squeezed, stroked, and touched without pain. Two and a half hours later the abnormal sensations had returned sufficiently for her to have to put the glove on again, though they had not returned to the head and neck. Some improvement lasted for $\mathbf{4 8}$ hours. Twenty-four hours after that an infusion of guanethidine $15 \mathrm{mg}$ in $30 \mathrm{ml}$ saline was given into the right arm. This had the same effect as the stellate block: all abnormal sensations disappeared and stimulation of the limbs no longer caused pain. This relief extended throughout the right side, including the leg, and lasted for 12 hours.

\section{CASE 8}

A 35-year-old man fell down a flight of stairs when he was drunk, hurting his right shoulder. Next morning he noticed that the tips of the third and fourth fingers of the right hand were numb; gradually the numbness spread to the other fingers. Some months later he found that he had become clumsy in doing up buttons. Myelography showed an expanded cord from the thoracocervical junction up to about the second cervical segment. The appearances were those of an intramedullary lesion, a long tumour being considered to be the most likely diagnosis. He was not operated on but was kept under observation.

His main difficulty eventually became the hypersensitivity of the right hand and dorsal surface of the forearm: even the lightest stimulation, such as the wind blowing, was painful. He avoided using the hand and held it in front of his chest to stop it being touched. Gradually he developed constant burning pain in the sensitive region. He sometimes experienced a sharp pain in the right axilla and down the medial sides of both forearms and noted that he could not appreciate temperature throughout the right arm.

Four years later another myelogram showed considerable expansion of the cervical and cervicothoracic regions of the cord. At operation to explore the lesion a tumour extending from the first to the seventh cervical segments was seen, which was shown on biopsy to be an astrocytoma. Neither the pain nor the hyperpathia was helped by the operation. Nine months later the patient returned, saying that he was suffering from numbness throughout the left side of his trunk, a sensation of pressure in both legs, aching in his neck, and extreme sensitivity in both forearms and hands with a burning or scalding pain that was relieved when he put his hands and forearms in hot water. The hyperpathia worsened progressively during the day so that by the evening wearing clothes was painful.

We concluded that the pain was causalgic in nature and due to the spinal lesion. The patient was admitted to hospital to try the effect of sympathetic blocks. As the pain and hyperpathia were in both arms a stellate block was performed on one side and regional guanethidine

TABLE I-Clinical features of cases

\begin{tabular}{|c|c|c|c|c|c|c|c|}
\hline $\begin{array}{l}\text { Case } \\
\text { No }\end{array}$ & Sex & Age & $\begin{array}{c}\text { Site and nature of } \\
\text { lesion }\end{array}$ & $\underset{\text { pain }}{\text { Burning }}$ & $\begin{array}{l}\text { Hyperpathia } \\
\text { and allodynia* }\end{array}$ & $\begin{array}{l}\text { Pain on } \\
\text { movement }\end{array}$ & $\begin{array}{l}\text { Duration of symptoms before } \\
\text { sympathetic blocks (years) }\end{array}$ \\
\hline $1+$ & $\bar{F}$ & 33 & \multirow{10}{*}{$\begin{array}{l}\text { Traumatic lesion of brain } \\
\text { stem } \\
\text { Thalamic syndrome: } \\
\text { vascular lesion } \\
\text { Thalamic syndrome: } \\
\text { vascular lesion } \\
\text { Thalamic syndrome: } \\
\text { vascular lesion } \\
\text { Traumatic central cervical } \\
\text { cord syndrome } \\
\text { Multiple sclerosis } \\
\text { Multiple sclerosis } \\
\text { Astrocytoma of cervical } \\
\text { cord }\end{array}$} & 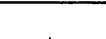 & 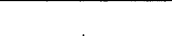 & 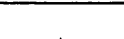 & , \\
\hline 2 & $\mathrm{~F}$ & 48 & & + & + & + & 1 \\
\hline 3 & $F$ & 60 & & + & + & + & 1 \\
\hline & & & & + & - & + & 4-5 \\
\hline $4^{\dagger}$ & F & 68 & & 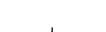 & + & 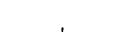 & ( \\
\hline 5 & $\mathbf{M}$ & 70 & & + & + & + & 1 \\
\hline \multirow{4}{*}{$\begin{array}{l}6 \\
7 \\
8+\end{array}$} & \multirow{4}{*}{$\begin{array}{l}F \\
F \\
M\end{array}$} & \multirow{4}{*}{$\begin{array}{l}45 \\
51 \\
42\end{array}$} & & + & + & + & 5 \\
\hline & & & & + & + & + & 1 \\
\hline & & & & + & + & + & \\
\hline & & & & + & + & + & 10 \\
\hline
\end{tabular}

*Allodynia is a term recommended by the International Association for the Study of Pain: it is a state in which pain is induced by a

stimulus that does not cause pain in normal skin.
+Cases described in text.

TABLE II-Effect of sympathetic blocks

\begin{tabular}{|c|c|c|c|c|c|c|}
\hline $\begin{array}{l}\text { Case } \\
\text { No }\end{array}$ & Type of block & $\begin{array}{l}\text { Duration of } \\
\text { effect (hours) }\end{array}$ & Effect on pain & $\begin{array}{l}\text { Effect on } \\
\text { hypersensitivity }\end{array}$ & Effect on movement & $\begin{array}{l}\text { Effect of guanethidine by } \\
\text { iontophoresis }\end{array}$ \\
\hline $\begin{array}{l}1^{*} \\
3\end{array}$ & \multirow{2}{*}{$\begin{array}{l}\text { Guanethidine } \\
\text { Sympathetic chain } \\
\text { Guanethidine: } \\
\text { First block } \\
\text { Second block } \\
\text { Third block } \\
\text { Sympathetic chain } \\
\text { Guanethidine } \\
\text { Sympathetic chain } \\
\text { Guanethidine }\end{array}$} & $\begin{array}{l}\text { Permanent } \\
1\end{array}$ & $\begin{array}{l}\text { Removed } \\
50 \% \text { removed }\end{array}$ & $\begin{array}{l}\text { Removed } \\
\text { Removed }\end{array}$ & $\begin{array}{l}\text { Improved } \\
\text { Could move without pain }\end{array}$ & \multirow[b]{3}{*}{$\begin{array}{l}\text { First occasion: reduction in } \\
\text { pain and tenderness } \\
\text { Second occasion: reduction in } \\
\text { pain and tenderness }\end{array}$} \\
\hline $\begin{array}{l}4^{*} \\
5\end{array}$ & & $\begin{array}{l}120 \\
\text { None } \\
40 \\
2 \cdot 5-48 \\
12 \\
20 \\
24\end{array}$ & $\begin{array}{l}\text { Much improved } \\
\text { None } \\
\text { Almost gone } \\
\text { Removed } \\
\text { Removed } \\
50 \% \text { removed } \\
\text { Slightly reduced }\end{array}$ & $\begin{array}{l}\text { Not present } \\
\text { Not present } \\
\text { Not present } \\
\text { Removed } \\
\text { Removed } \\
50 \% \text { removed } \\
\text { Slight improvement }\end{array}$ & $\begin{array}{l}\text { Much improved } \\
\text { None } \\
\text { Much improved } \\
\text { Could move without pain } \\
\text { Could move without pain } \\
\text { Improved } \\
\text { Improved }\end{array}$ & \\
\hline 6 & $\begin{array}{l}\text { Guanethidine: } \\
\text { First block } \\
\text { Second block } \\
\text { Third block } \\
\text { Fourth block } \\
\text { Fifth block }\end{array}$ & $\begin{array}{l}4-6 \\
60 \\
20 \\
20-24 \\
4-6\end{array}$ & $\begin{array}{l}\text { Removed } \\
\text { Removed } \\
75 \% \text { removed } \\
50 \% \text { removed } \\
\text { Removed }\end{array}$ & $\begin{array}{l}\text { Removed } \\
\text { Removed } \\
\text { Removed } \\
50 \% \text { removed } \\
\text { Removed }\end{array}$ & $\begin{array}{l}\text { Much improved } \\
\text { Much improved } \\
\text { Much improved } \\
\text { Much improved } \\
\text { Improved }\end{array}$ & \\
\hline 7 & $\begin{array}{l}\text { Guanethidine: } \\
\text { First block }\end{array}$ & 2 & Slight & Slight & Slight & \multirow{2}{*}{$\begin{array}{l}\text { Less than } 50 \% \text { tenderness } \\
\text { removed }\end{array}$} \\
\hline \multirow[t]{3}{*}{$8^{*}$} & $\begin{array}{l}\text { Second block } \\
\text { Third block } \\
\text { Sympathetic chain: } \\
\text { Guanethidine: }\end{array}$ & $\begin{array}{l}60 \\
3 \\
1\end{array}$ & $\begin{array}{l}50 \% \text { removed } \\
50 \% \text { removed } \\
\text { Removed most }\end{array}$ & $\begin{array}{l}75 \% \text { improved } \\
33 \% \text { improved } \\
\text { Much reduced }\end{array}$ & $\begin{array}{l}\text { Could move without pain } \\
\text { Improved } \\
\text { Improved }\end{array}$ & \\
\hline & First block & 1 & $50 \%$ removed & Improved & Improved & \multirow{2}{*}{$\begin{array}{l}\text { First occasion: tenderness } \\
\text { removed } \\
\text { Second occasion: tenderness } \\
\text { removed }\end{array}$} \\
\hline & Second block & 1 & $50 \%$ removed & Improved & Improved & \\
\hline
\end{tabular}

* Cases described in text. 
given to the other. An infusion of $15 \mathrm{mg}$ guanethidine in $30 \mathrm{ml}$ saline was given into the right arm; at the same time the left stellate ganglion was blocked with $8 \mathrm{ml}$ bupivacaine. The improvement lasted about an hour in both arms. The pain relief was slightly better on the side blocked by local anaesthetic into the stellate ganglion, and the improvement in the sensitivity was better in that arm. The patient could move both arms without inducing much pain. On another occasion $15 \mathrm{mg}$ guanethidine in $30 \mathrm{ml}$ saline was infused into the right arm. The effects were the same as those of the previous infusion of guanethidine but lasted only an hour. On two occasions guanethidine 5\% was given iontophoretically into the terminal phalanges of the fifth and fourth fingers. The difference in sensitivity between these phalanges and the proximal untreated phalanges was considerable. The terminal phalanges could be stroked, pressed, and touched lightly without any pain being induced.

\section{Discussion}

These cases show that chronic pain and hyperpathia arising from a lesion in the central nervous system may be abolished by blocking the sympathetic supply to the periphery. This peripheral block also caused an improvement in the motor effects of a thalamic lesion-namely, dystonic posture and involuntary movements with co-contraction of agonists and antagonists. The lesions were at various sites within the central pathways. Thus we conclude that sympathetic blocks relieve certain abnormal painful states whether the lesion causing them is peripheral or central.

The central and peripheral states have in common the burning pain and extreme sensitivity on stimulation; in this hyperpathic state all kinds of stimulation cause penetrating burning pain or a feeling like a burning electric shock. Loh and Nathan ${ }^{1}$ reported that sympathetic blocks were most likely to relieve pain in peripheral nerve lesions when this was burning pain accompanied by hyperpathia. To remove this state, whether it is due to a peripheral or a central lesion, not all the peripheral nerves of the affected region have to have their sympathetic nerve supply blocked, as was seen in cases 3 and 4 . In case 3 the pain was removed from the neck and ear and movements of the shoulder were easier: all of these regions were above the region into which guanethidine had been infused. In case 4 blocking the sympathetic supply of the face, head, and arm by injecting local anaesthetic into the stellate ganglion relieved the manifestations of the thalamic syndrome not only in these regions but also in the leg. Nevertheless, it appears that a certain length of the peripheral nerves of the limb has to be affected by the guanethidine, for when guanethidine was driven by iontophoresis into the tissues of the two terminal phalanges the hyperpathic state was removed only in those phalanges. Thus blockade of the sympathetic supply of peripheral tissues restores a normal state even though the lesion remains in the central nervous system. The removal of the abnormal state by sympathetic blocks was temporary in six patients, but in two more lasting relief of pain occurred.

Two different hypotheses suggest themselves to account for the removal of the pain and hyperpathic state and improvement in motility.

One hypothesis is that the peripheral nerves, both afferent and sympathetic, are in a normal state and that central afferent pathways or nuclei are in an abnormally excitable state due to the central lesion. In this case normal activity of the afferent peripheral nerves adds to an abnormal, perhaps disinhibited, state in central structures. Blocking the somatic nerves or blocking the sympathetic outflow removes or reduces the input to the abnormal central structures, thereby removing or reducing their abnormal excitability. Why blocking the sympathetic outflow should have an effect on afferent peripheral nerves or their receptors, or both, is uncertain: it may be related to the admittedly inconsistent evidence that the sympathetic system controls, alters, or influences receptors, afferent nerve fibres, and posterior root ganglia, ${ }^{3-5}$ in which case blocking the sympathetic outflow would be like blocking the peripheral input to a central lesion; this also stops pain and dysaesthesia originating within the central nervous system. ${ }^{6}$

The other hypothesis is that damaged central neurons make neurons in contact with them abnormal. This abnormal state passes transsynaptically from neuron to neuron so that finally abnormal function of the peripheral afferent nerves or autonomic nerves, or both, results. One possible mechanism might be the absence of trophic substances due to the destruction of central $s$ neurons. Although there is usually no clinical evidence of impaired peripheral nerve function, a cerebral lesion can cause 0 trophic disturbances in the contralateral limbs. Arseni and Botez ${ }^{7} 7$ reviewed relevant reports and added cases of their own. One of the more obvious examples of this condition is the shoulderhand syndrome occurring after a stroke. This can also occur paroxysmally, as in the case of hemiplegic migraine. ${ }^{8}$

Finally, from a practical point of view, we suggest that patients with central lesions, such as the thalamic syndrome, who have hyperpathia and pain on movement should have the sympathetic supply of the affected region blocked to see whether this causes any temporary change in the state; if it does it might be repeated in the hope of achieving lasting alleviation of the intractable pain. While repeated sympathetic blocks may be well worth while, we have not so far undertaken surgical sympathectomy in these cases. Nearly all studies dealing with sympathectomy for causalgia and similar pains have been in patients with damage affecting the peripheral nervous system; in addition, the institution of early treatment has been emphasised by many workers. ${ }^{9}$ We have therefore hesitated from recommending surgical procedures in our patients, whose pain is chronic and arises from within the central nervous system.

We are grateful to Professor R W Gilliatt, Dr Peter Rudge, and Mr Laurence Walsh for allowing us to investigate their patients.

\section{References}

1 Loh L, Nathan PW. Painful peripheral states and sympathetic blocks. f Neurol Neurosurg Psychiatry 1978;41:664-71.

${ }^{2}$ Hannington-Kiff J. Intravenous regional sympathetic block with guanethidine. Lancet $1974 ; \mathrm{i}: 1019-20$

3 Santini M. Towards a theory of sympathetic sensory coupling: the primary sensory neuron as a feedback target of the sympathetic terminal. In: Zotterman Y, ed. Sensory functions of the skin in primates. Oxford: Pergamon Press, 1976:15-35.

4 Procacci P, Marchetti G, Buzzelli G, Rocchi P. Effetti del blocco farmacologico del ganglio stellato sulla sensibilita dolorifica cutanea nell individuo sano. Arch Fisiol 1963;62:332-42.

5 Procacci P, Francini F, Zoppi M, Maresca M. Cutaneous pain threshold changes after sympathetic blocks in reflex dystrophies. Pain 1975;1: 167-75.

${ }^{6}$ Kibler RF, Nathan PW. Relief of pain and paraesthesiae by nerve block distal to a lesion. 7 Neurol Neurosurg Psychiatry 1960;23:91-3.

7 Arseni G, Botez MI. Tulburări viscero-vegetative si trofice în leziunile encefalice. Bucharest: Editura Academiei Republicii Socialiste Romania, 1971.

8 Montgomery BM, King WW. Hemiplegic migraine; a case with paroxysmal shoulder-hand syndrome. Ann Intern Med 1962;57:450-5.

9 Bonica JJ. Causalgia and other'reflex sympathetic dystrophies. In: Bonica JJ, Liebeskind JC, Albe-Fessard DG, eds. Advances in pain research and therapy. Vol 3. New York: Raven Press, 1979:141-66.

(Accepted 19 fanuary 1981)

\section{Correction}

Effect of hyperlipidaemia on haemostatic variables

An error occurred in this paper by Dr R S Elkeles and others $(11$ October $1980, p$ 973). Ten of the 11 people studied were hospital patients. One was a participant in the Northwick Park Heart Study. . . (1) 